\title{
'Moixent', an Apricot Resistant to Sharka
}

\author{
Jose Martínez-Calvo, Gerardo Llácer, and Maria Luisa Badenes ${ }^{1}$ \\ Instituto Valenciano de Investigaciones Agrarias (IVIA), Apartado Oficial: \\ 46113, Moncada (Valencia), Spain
}

Additional index words. fruit breeding, Prunus armeniaca, sharka resistance, fruit quality

\begin{abstract}
'Moixent' is a self-compatible, earlyripening apricot cultivar (Prunus armeniaca L.) with excellent fruit quality and resistance to sharka (plum pox virus), a serious disease limiting apricot fruit production in affected areas. 'Moixent' fruits have excellent organoleptic characteristics, significantly improved from other early cultivars available in the market. 'Moixent' is well adapted to areas with warm winter and Mediterranean climate and presents good fruit set and productivity.
\end{abstract}

\section{Origin}

'Moixent' resulted from a cross made in 1996 in Valencia, Spain, between the North American cultivar Goldrich (Washington State University) and a Spanish cultivar, of unknown origin, Miger (Fig. 1). The objectives of the cross were to obtain early- to midripening sharkaresistant new cultivars with good fruit quality, self-compatibility, and larger fruit size than the local apricot cultivars grown in Valencia. 'Goldrich' was selected as the sharka-resistant female parent with large fruit size and better adaptability to warm winters than other resistant cultivars and 'Miger' was used as a male parent as a result of its large size, excellent fruit quality, and the selfcompatibility trait.

\section{Description}

\section{Tree characteristics}

Tree description. 'Moixent' was selected originally as an elite line planted on its own roots as we currently do in the program with all seedlings obtained. After a first selection for its fruit quality, buds were grafted on apricot rootstocks and planted in experimental plots in different climatic areas located in the Valencia and Murcia regions for a second step of selection focused on agronomic traits. Four trees per plot were planted at regular local distances $(5 \times 4 \mathrm{~m})$ and were maintained by standard cultural practices. Data from phenology and fruit traits are presented in Table 1; all data were collected during four growing seasons, initiating data collection

Received for publication 30 Dec. 2010. Accepted for publication 26 Jan. 2011.

This work was developed in the framework of the apricot breeding program developed at IVIA funded by the Spanish Ministry of Science and Technology grants AGL2007-60709 and AGL2010-20595.

${ }^{1}$ To whom reprint requests should be addressed; e-mail badenes_mlu@gva.es. when the trees were 4 years old at the IVIA (Valencia, Spain) experimental plot (long. 39 $34^{\prime} \mathrm{N}$, lat. $024^{\prime} \mathrm{W}$, alt. $55 \mathrm{~m}$ ). 'Moixent' grows vigorously with a spreading growth habit, displays vegetative budbreak in the last week of March, and has an average mean yield of $83 \mathrm{~kg} /$ tree (Table 1).

Plum pox virus resistance. Sharka disease, caused by the plum pox virus (PPV), is the most limiting factor for apricot production in those areas affected by the virus (Kölber, 2001). During the 1980s and 1990s, apricot production was seriously affected by PPV in Spain, France, and Italy causing significant losses to the crop (Roy and Smith, 1994). All local apricot cultivars are susceptible to PPV and the removal of infected trees was ineffective in eradicating the disease in Spain (Llácer and Cambra, 1998). Several cultivars from North America such as 'Goldrich', 'Sunglo', 'Orange Red', and 'Stark Early Orange' show resistance to PPV and are used frequently as parents in breeding programs (Egea et al., 1999). In the case of 'Moixent', 'Goldrich' was used as a donor of resistance. Evaluation of PPV resistance was carried out in controlled greenhouse conditions following the procedure described by Moustafa et al. (2001). Six replicates of 'Moixent' grafted on peach GF305 inoculated with PPV were studied for two growing cycles. The plants were tested for the presence of the virus by enzyme-linked immunosorbent assay and by reverse transcription-polymerase chain reaction using primers unique to the isolate. No symptoms were observed on all plants tested and the presence of the virus was not detected by either analysis method. Additionally, three trees per accession were planted in areas heavily infected with PPV. These trees were surrounded by infected, susceptible cultivars and inoculated by chip budding in the open field with the Diderontype PPV isolate (López-Moya et al., 2000). No symptoms were observed 3 years after inoculation, whereas PPV symptoms were observed in the neighboring susceptible trees. Results showed that 'Moixent' is resistant to the Dideron-type PPV isolates.

Time of bloom and floral compatibility. Full bloom of 'Moixent' occurs in the second week of March, which is the average flowering date of its parents (Table 1). 'Moixent' has a high flowering set, mainly localized on the fruiting spurs $(85 \%)$ of 2 years or older branches; flower bud drop was medium and it has self-compatible flowers.

The self-compatibility of 'Moixent' was demonstrated in the field by bagging all the trees using an insect proof net and in the laboratory using molecular markers derived from RNA sequences developed by Vilanova et al. (2005).

\section{Fruit and tree characteristics}

Maturation time. 'Moixent' is a mid- to early-ripening cultivar in comparison with the traditional Spanish apricot cultivars. In our experimental conditions, the average ripening date of 'Moixent' was 2 June (Table 1). The fruits of 'Moixent' are localized mainly in

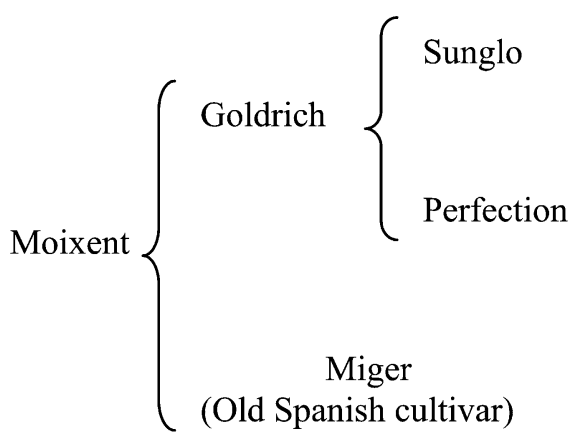

Fig. 1. Pedigree of 'Moixent' apricot.

Table 1. Tree and fruit characteristics of 'Moixent', 'Miger', and 'Goldrich' under experimental conditions at IVIA, Valencia, Spain.

\begin{tabular}{lccc}
\hline Characteristics & Moixent & Miger & Goldrich \\
\hline Tree & High & Medium & High \\
Vigor & 27 Mar. & 30 Mar. & 1 Apr. \\
Vegetative bud break & 9 Mar. & 12 Mar. & 24 Mar. \\
Average full bloom date & High & Medium & Medium \\
Flower set & Self-compatible & Self-compatible & Self-incompatible \\
Floral compatibility & 9 & 7 & 6 \\
Yield $(1-9)$ & & & \\
Fruit & 2 June & 2 June & 16 June \\
Average ripening date & Yelloy & Yellow & Orange \\
Skin ground color & 35 & 40 & - \\
Percent red blush & High & High & - \\
Intensity over color & Light orange & Cream & Orange \\
Flesh color & 83 & 70 & 69 \\
Fruit weight $(\mathrm{g})$ & 0.7 & 1.0 & 0.8 \\
Firmness $(\mathrm{kg})$ & 15 & 14 & 13.5 \\
Soluble solids $\left({ }^{\circ}\right.$ Brix $)$ & 17 & 15 & 24 \\
Acidity $\left(\mathrm{g} \cdot \mathrm{L}^{-1}\right.$ malic acid) & & & \\
\hline
\end{tabular}




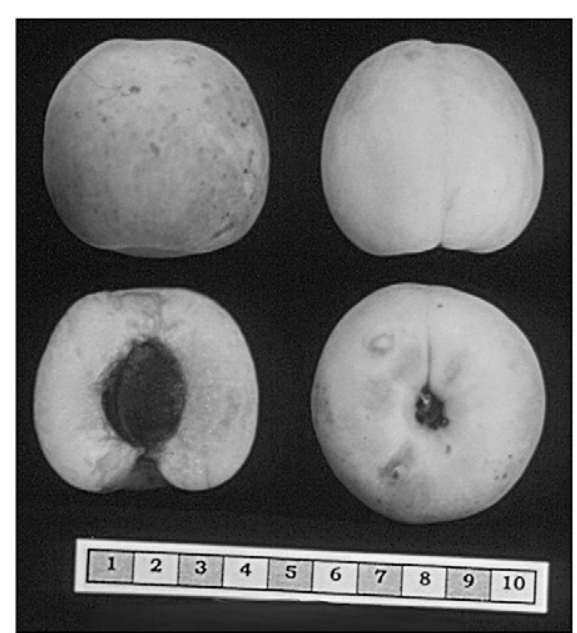

Fig. 2. Fruits from 'Moixent' variety.

fruiting spurs (95\%). Although the chilling requirement was not measured, this variety showed very good adaptability in areas located in Valencia and Murcia with medium chilling.

Fruit size, firmness, and color. Fruit characters were studied at the physiological maturity stage on 25 fruits (Fig. 2). Fruits of 'Moixent' are round, symmetric, with a medium deep suture, without bumps in the skin, freestone, and with pubescence. The skin ground color is yellow with a solid red blush over color covering $\approx 35 \%$ of the fruit; the incidence of cracking is low. The flesh is light orange. The average size is $\approx 53.1 \mathrm{~mm}$ (diameter) with an average weight of $82.7 \mathrm{~g}$ and an average firmness of $1.4 \mathrm{~kg} \cdot \mathrm{cm}^{-2}$.

Organoleptic characteristics. At the physiological maturity stage, 'Moixent' fruits are juicy and sweet $\left(15.1^{\circ}\right.$ Brix on average) and slightly acidic (16.8 g. $\mathrm{L}^{-1}$ malic acid on average) (Table 1) and the overall taste is excellent with plenty of aroma.

\section{Availability}

The Moixent cultivar is protected by the Spanish Office for Varietal Protection with the registration number 2008/4813. Virusfree plants are available from authorized nurseries in Spain registered at $<\mathrm{http}: / / \mathrm{www}$. agroalimed.es $>$. The plants are tested and free of the following viruses: PPV, Prune dwarf ilarvirus (PDV), Prunus necrotic ringspot ilarvirus (PNRSV), Apple chlorotic leafspot closterovirus (CLSV), and Apple mosaic ilarvirus (ApMV).

\section{Literature Cited}

Egea, J., L. Burgos, P. Martínez-Gómez, and F. Dicenta. 1999. Apricot breeding for sharka resistance at CEBAS-CESIC, Murcia (Spain). Acta Hort. 121:207-210.

Kölber, M. 2001. Workshop on Plum pox. Acta Hort. 550:249-255.

Llácer, G. and M. Cambra. 1998. Thirteen years of sharka disease in Valencia, Spain. Acta Hort. 472:379-384.

López-Moya, J.J., M.R. Fernández-Férnandez, M. Cambra, and J.A. García. 2000. Biotechnological aspects of Plum pox virus. J. Biotechnol. 76:121136.

Moustafa, T.A., M.L. Badenes, J. Martínez-Calvo, and G. Llácer. 2001. Determination of resístanse to sharka (plum pox) in apricot. Scentia Hort. 91:59-70.

Roy, A.S. and I.M. Smith. 1994. Plum pox situation in Europe. EPPO Bulletin 24:515-524.

Vilanova, S., C. Romero, L. Burgos, G. Llácer, and M.L. Badenes. 2005. Identification of self(in) compatibility alleles in apricot by PCR and sequence analysis. J. Amer. Soc. Hort. Sci. 130: 893-898. 